\author{
BULETINUL INSTITUTULUI POLITEHNIC DIN IAŞI \\ Publicat de \\ Universitatea Tehnică „Gheorghe Asachi” din Iaşi \\ Volumul 67(71), Numărul 1, 2021 \\ Secţia \\ CONSTRUCTTII. ARHITECTURĂ \\ DOI: $10.2478 /$ bipca-2021-0007 \\ Sciendo
}

\title{
A REVIEW ON THE ENERGY PERFORMANCE AND EFFICIENCY OF RADIANT FLOOR HEATING SYSTEMS WITH INTEGRATED PHASE CHANGE MATERIALS
}

BY

\section{MARIUS BRĂNOAEA* ${ }^{*}$ and ANDREI BURLACU}

\author{
„Gheorghe Asachi” Technical University of Iasi, Faculty of Civil Engineering and Building \\ Services, Iasi, Romania
}

Received: March 12, 2021

Accepted for publication: March 24, 2021

\begin{abstract}
In the modern society the concept of energy efficiency of buildings has become a subject of great interest, due to the negative impact of buildings upon the environment, society and economy. One of the methods of overcoming this is to provide a better efficiency of the energy storage because it is the key to resolve the difference between supply and demand. In comparison to electro-chemical batteries which provide limited energy storage at a high financially cost, thus in this regard, thermal energy storage technologies with high energy density have increased market potential. PCMs present objective advantages in comparison to classic construction materials due to their characteristics of being able to store and release higher quantities of thermal energy during the phase change process. A PCM radiant floor heating system can provide a reduction of the energy consumption for heating by up to $43 \%$, trough the higher discharge time of the PCM compared to regular heating systems.
\end{abstract}

Keywords: Phase Change Material, Floor heating, Energy efficiency, Energy consumption reduction, Space heating performance

\footnotetext{
*Corresponding author; e-mail: marius.branoaea@tuiasi.ro (C) 2021 Marius Brănoaea and Andrei Burlacu

This is an open access article licensed under the Creative Commons Attribution-NonCommercialNoDerivatives 4.0 International License (CC BY-NC-ND 4.0).
} 


\section{Introduction}

Due to the rapidly increase of urbanization, deforestation, global climate change and the increased demand for indoor thermal environments caused by the rise of indoor residence time, the energy consumption of buildings represent $40 \%$ of the global energy consumption and accounts to over $30 \%$ of the global emissions of CO2 (Cao, Dai and Liu 2016).

A large portion of the electric energy demand in the residential sector is caused by heating and cooling. Considering this, the implementation of solutions that have the purpose of increasing the energy efficiency in buildings has become an urgent matter.

Phase change materials (PCMs) can provide the missing link in the supply and demand chain due to their properties of storing heat in time. PCMs are very advanced energy storage materials (Guarino, et al. 2017), capable of storing energy in the form of latent heat according to the temperature differences. When the temperature decreases, the material releases the stored energy by switching its phase from liquid to solid in order to reduce the energy demand (Magendran, Khan, et al., Synthesis of organic phase change materials by using carbon nanotubes as filler material 2019).

The storage of thermal energy using phase change materials has become a pertinent research topic in recent years, being the centre of interest of researchers around the world in very diverse fields, due to the ability to reduce the energy demand.

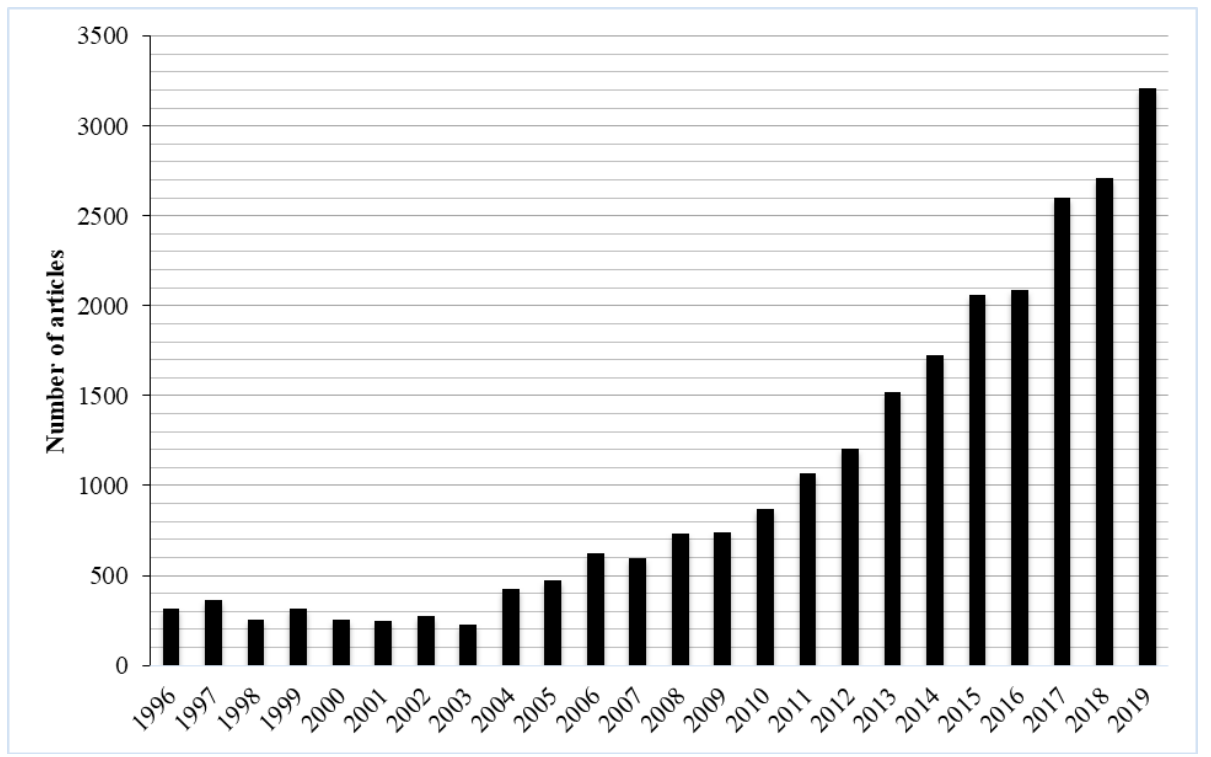

Fig. 1 PCM publication between 1996 and 2019 
In the last decade the interest for PCMs has increased, a result to the incorporation of PCMs in construction materials was the increase in the number of publications of research articles, as presented in Fig. 1, in order to meet the concerns regarding energy efficiency, energy consumption and sustainable construction.

The increase in the number of publications related to phase change materials emphasized the goals for Horizon 2020 and proves the interest of the scientific community towards providing modern, reliable, sustainable and affordable energy sources.

\section{Energy efficiency}

The increasingly energy demand throughout the world represents one of the main reasons for the unstable development and the degradation of our planet. The surge in world population and the increase in energy accessibility for more and more people justifies the increase in energy demand. The exploitation and consumption of non-renewable fossil fuels that have a high impact to the environment are currently the main source of energy production, but the major drawback is the greenhouse gas emissions which pose a great threat to the environment. Furthermore, energy demand has a substantial contribution towards the GDP growth of a country, the energy demand is elastic in both the household/services sector and the industrial sector and in the European union electricity and natural gas serve as demand substitutes (Akalpler and Shingil 2017, Fotis, Karkalakos and Asteriou 2017).

In the past decades, the interest towards climate change mitigation has increased on an international scale. Following this trend, the EU adopted in 2012 a legislation with the target to reduce the emissions of greenhouse gases until 2020 by $20 \%$ compared to the values of 1990 . Studies performed in 2017 showed that these conditions would not be met, and as a result the restrictions were increased, the targets for 2030 demanded a decrease of $27 \%$ in energy consumption and a reduction of greenhouse gas emissions by $40 \%$ (Cambeiro, et al. 2019).

In order to increase the energy efficiency of buildings and reduce their energy consumption modernization is a viable method, this being on the same line as one of the objectives and measures proposed by the United Nations, buildings energy rehabilitation until 2030 (Cambeiro, et al. 2019).

In the last decades, especially after 1990, the construction sector put a high emphasis on increasing the energy efficiency of buildings, this was the case as a result to the strict regulations implemented in the real estate sector. As a result, in the following years the energy consumption decreased, in the year 2002 the reduction reached $24 \%$, but the European renovation rate is less than $2.5 \%$ of the existent buildings (Cambeiro, et al. 2019). 
Considering these factors, a method of overcoming these shortcomings is the implementation of novel building materials with better thermal energy storage capacities.

\section{Thermal energy storage}

Thermal energy storage is a method to increase the energy efficiency of buildings.

Thermal energy storage can be classified in two main categories sensible heat storage and latent heat of storage.

Sensible heat storage can be achieved using a fluid or a solid and increasing their temperature without phase change, utilizing the thermal mass of the materials, this is the case for most conventional construction materials, the amount of sensible heat that is stored is dependent by the material heat capacity and the rate at which the heat can be stored and released (thermal diffusivity) (Belz, et al. 2015).

Latent heat storage is based on the phase transition of a material. The most common use of phase transition is using solid-liquid phase change, through melting and solidification of the material. By melting, the material stores large quantities of heat while maintaining a constant temperature and through solidification this heat is released. The materials that use latent heat storage are called phase change materials (PCM) (Belz, et al. 2015).

In comparison to sensible heat storage, latent heat storage has a much higher energy density.

\section{Phase change materials}

Scientific research show that there are numerous methods of harnessing thermal energy, but among them phase change materials present objective advantages due to their characteristics of being able to store and release higher quantities of thermal energy during the phase change process, being considered a favourable option (Magendran, Khan, et al., Synthesis of organic phase change materials (PCM) for energy storage applications: A review 2019).

The melting-solidification cycle is presented in Fig.2 


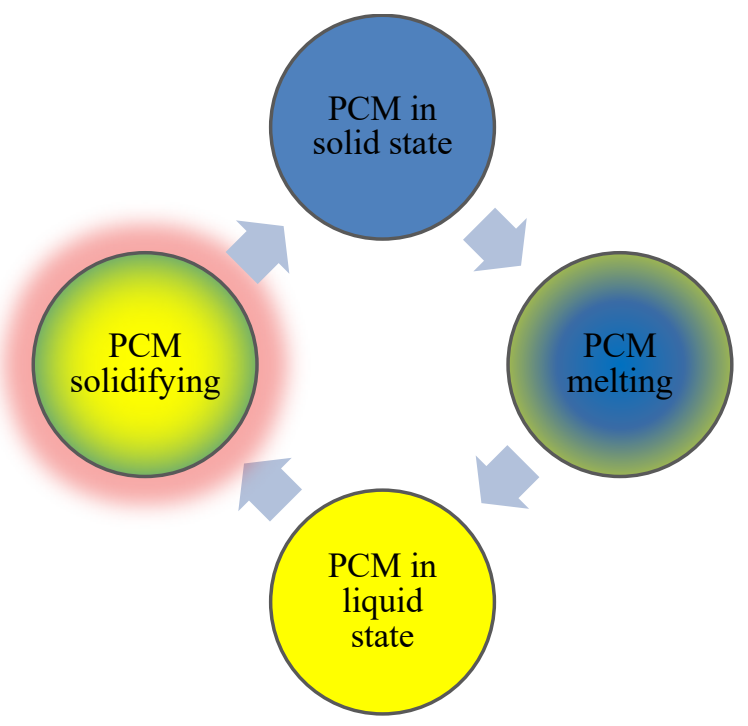

Fig. 2. PCM melting and solidification cycle

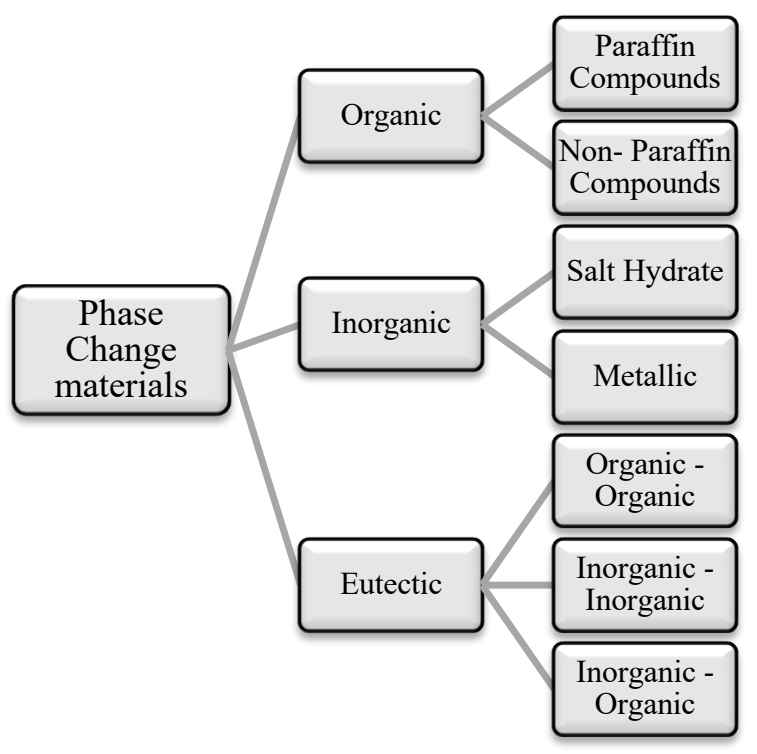

Fig. 3. PCM classification

In terms of classification, phase change materials can be divided by different properties. 
Regarding the type of substance, phase change materials can be characterized as solid-solid PCMs, solid-liquid PCMs, solid-gas PCMs, and liquid-gas PCMs (Lin, et al. 2018). Among these 4 types of PCMs, the most commonly used are solid-solid PCMs because these present some advantages in comparison to the other categories, during the phase change these present high latent heat capacity with negligible change in terms of volume.

The solid-liquid PCMs can be furthermore classified based on their chemical properties into organic PCMs, inorganic PCMs and eutectic PCMs, which can be further classified as shown in Fig.3.

Not all PCMs are used in practical applications. The most important characteristics of PCMs are: (1) The temperature at which the phase change occurs is within practical operation temperature range. (2) Increased latent heat storage capacity. (3) High thermal conductivity. (4) Stable in terms of thermal chemical and properties. (5) Non-toxic, non-corrosive and harmless to environment. (6) Low cost and easily available. (7) Reduced cost and increased availability. (8) Zero or reduced supercooling.

\subsection{Organic PCMs}

These types of PCMs present the following advantages: wide range of working temperatures, fusion presents high latent heat, non-reactive, liquid state undercooling capability is low, high nucleation rate, consistent phase change, auto-nucleation properties, non-corrosive, thermally and chemically stable, low segregation, recyclable and can be implemented in buildings.

The main disadvantages consist of high cost, low thermal conductivity, low enthalpy, low density, increased volume variation during phase change and flammable (Cunha and Aguiar 2020).

\subsection{Inorganic PCMs}

These type of phase change materials are divided in hydrated salts and metallic salts.

Metallic salts are not an appealing research topic for thermal energy storage because of their weigh, but hydrated salts PCMs have been extensively studied due to their properties.

Inorganic PCMs have as main advantages: low cost, reduced volume variation during phase change, high enthalpy, high thermal conductivity, easily accessible, non-flammable, low impact on the environment, compatible with plastic containers and as main drawbacks corrosive to metals, phase subcooling drawbacks, slightly toxic, low thermal stability, phase change presents material separation and incompatible with some construction materials (Cunha and Aguiar 2020). 


\subsection{Eutectic PCMs}

These type of phase change material is obtained by combining two or multiple PCMs, either organic or inorganic or a combination of these two, in order to form a material specially designed to the existing need in terms of transition temperature, in comparison to the base components. The main disadvantage is the high production cost, reaching several times the cost of the base components.

\section{Building applications of PCMs}

Phase change materials have a large number of applications in both passive and active systems, their primary role is thermal energy storage.

In terms of applications in buildings researchers have integrated phase change materials in building elements such as: walls (Kong, et al. 2020, Wang, et al. 2020, Rathore and Shukla 2019), windows (Li, et al. 2018, Hu and Heiselberg 2018), ceilings (Weinläder, Klinker and Yasin 2017, Yasin, et al. 2019) and floors (Yun, et al. 2019, Lu, Xu and Tang 2020, Faraj, et al. 2019, Guo, et al. 2020, Mays, et al. 2017, Devaux and Farid 2017)

Among the conventional heating systems floor heating systems can provide objective advantages in comparison to traditional heating systems. The main advantages start from: uniform heating provided by heating the entire floor, in comparison to classic radiant heating systems or forced-air that cause differences in the room temperature, as a result providing increased comfort, higher energy efficiency, in comparison to traditional radiators that require a temperature of the working fluid ranging between $65-75^{\circ} \mathrm{C}$, radiant floor heating systems need to be heated up to $30^{\circ} \mathrm{C}$, requiring less energy as a result, more space in comparison to even the most modern radiators requiring space on the walls and no noise in comparison to forced-air systems. The main disadvantages of floor heating systems consist of a higher installation cost and an increased difficulty of application in existing buildings, necessitating the replacement of the floor.

Underfloor heating systems can be classified in two main categories based on the heating system: wet floor heating system, which uses water as a working fluid that flows through pipes in order to heat the floor and dry floor heating systems, which use heating mats or electric heating wires connected to the main electricity supply.

The study conducted by ( $\mathrm{Lu}, \mathrm{Xu}$ and Tang 2020) over a period of 26 days analysed the operation effect of a wet floor heating system integrated with a double pipe PCM in four operating strategies. The study highlighted the following benefits of integrating a PCM in a floor heating system: the heating equipment maintained an average indoor temperature of $18.9^{\circ} \mathrm{C}$ with the daily temperature fluctuation of $2.1{ }^{\circ} \mathrm{C}$ achieving thermal comfort operating at partial power. 
In terms of dry floor heating systems integrated with PCMs (Devaux and Farid 2017) modelled two huts in the campus at University of Auckland, New Zealand, integrating PCMs in the underfloor heating system. Two types of PCMs were used in the study with different melting points in order to achieve a balance between energy consumption, a PCM with a higher melting point providing notable peak load shifting, and indoor comfort provided by a PCM with a lower melting point applied in the walls and the ceiling. After testing the system over a period of 10 days, the resulted energy savings was $32 \%$ and a reduction in the heating costs due to a reduction in energy consumption and peak load shifting was $42 \%$.

Another dry floor heating system analysed by (Yun, et al. 2019), included multiple types of PCMs with varying melting points between $28{ }^{\circ} \mathrm{C}$ and $35^{\circ} \mathrm{C}$, fabricated in a special form, Macro-Packed PCM, in order to provide shape stabilization of the material during the phase change and the liquid phase. Yun, et al. analysed two cases, the PCM placed above the electrical heating panel and the PCM placed under the panel. The measurements and the calculated energy consumption highlighted that by integrating a PCM in the floor, produces a reduction in the energy consumption from $8 \%$ to $42 \%$ depending on the type of the PCM and its melting point.

A study conducted by (Faraj, et al. 2019) analysed the thermal performance of a natural PCM, bio-based coconut oil placed in an aluminium container integrated in an electrical floor heating system. The thermal performance of the PCM integrated system was analysed in comparison with a similar system without the presence of the PCM, the tests being conducted in an agricultural refrigerator in order to simulate winter conditions. The PCM integrated system had a charge phase in order to reach the indoor temperature of $22{ }^{\circ} \mathrm{C}$ of $2.08 \mathrm{~h}$ and a discharge phase of $3.50 \mathrm{~h}$, and the classic system presented a lower charge phase of $0.89 \mathrm{~h}$ and a reduced discharge phase of $1.41 \mathrm{~h}$. The drawback of the higher charging phase of the PCM integrated system is compensated by the increased discharge time, thus requiring 4.32 daily heatingcooling cycles in comparison to the regular system that requires 10.40 daily heating-cooling cycles, resulting in a reduction in the operation costs of the heating system of $58.9 \%$.

\section{Conclusions}

Phase change materials can provide significant energy reduction in terms of the energy consumption used for heating.

The main advantage of the phase change materials is the capacity to store and release more thermal energy in comparison to classic construction materials, managing to overcome the drawback of having a higher charge time through the reduction in the number of charge-discharge cycles in a day. 
In terms of flexibility, a wide range of phase change materials can be used, starting from organic phase change materials to inorganic or even eutectic, a combination of multiple PCMs, in order to apply this system in every climatic region.

Depending on the type of PCM integrated in the floor heating system a reduction in the heating cost can be achieved ranging from reduced amounts of $8 \%$ to significant amounts of nearly $50 \%$.

The research show that by integrating phase change materials in floor heating systems a reduction in the energy consumption can be achieved, but further studies and improvements are necessary in order to achieve an application ready to implement on a large scale.

One of the future research trends is studying the type of phase change material that is integrated in the system in order to reach an ideal balance between melting temperature, PCM conductivity and heat capacity. In this regard both organic or inorganic PCMs can be studies or a eutectic PCM, a combination or multiple PCMs.

Another very significant research trend is the study of the encapsulation method of the phase change material, because the material is performing multiple charge/ discharge cycles in a day and during the melting process the volume might change, this can result in the deterioration of the floor, thus the encapsulation of the PCM is necessary. Furthermore, the encapsulation method of the PCM should be chosen in order to achieve a good cooperation with both dry and wet floor heating systems.

Further research can be carried out regarding the integration of very efficient heat transfer devices such as heat pipes in the PCM integrated floor heating system, in order to overcome one of the main disadvantages of the PCM, the low conductivity, thus reducing the charging phase and managing to heat the radiant floor faster.

\section{REFERENCES}

Akalpler E., Musa E. S., Statistical reasoning the link between energy demand, CO2 emissions and growth: Evidence from China, Procedia Computer Science, 120, 182-188, (2017).

Belz K., Kuznik F., Werner K. F., Schmidt T., Ruck W. K. L., Thermal energy storage systems for heating and hot water in residential buildings, In Advances in Thermal Energy Storage Systems, by Luisa F. Cabeza, 441-465, (2015). Woodhead Publishing Series in Energy.

Cambeiro F. P., Julia A., Guillermo B., Juan I. P. L., Faustino P. B., Economic appraisal of energy efficiency renovations in tertiary buildings, Sustainable Cities and Society, 47, 101503, (2019).

Cao X., Xilei D., Junjie L., Building energy-consumption status worldwide and the stateof-the-art technologies for zero-energy buildings during the past decade, Energy and Buildings, 128, 198-213, (2016). 
Cunha S. R. L., José L. B. A., Phase change materials and energy efficiency of buildings: A review of knowledge, Journal of Energy Storage, 27, 101083, (2020)

Devaux P., Mohammed M. F., Benefits of PCM underfloor heating with PCM wallboards for space heating in winter, Applied Energy, 191, 593-602, (2017)

Faraj K., Jalal F., Farouk H., Hassan B., Mahmoud K., Cathy C., Analysis of underfloor electrical heating system integrated with coconut oil-PCM plates, Applied Thermal Engineering, 158, 113778, (2019)

Fotis P., Sotiris K., Dimitrios A., The relationship between energy demand and real GDP growth rate: The role of price asymmetries and spatial externalities within 34 countries across the globe, Energy Economics, 66, 69-84, (2017)

Guarino F., Andreas A., Maurizio C., Diane B., PCM thermal storage design in buildings: Experimental studies and applications to solaria in cold climates, Applied Energy, 185, 95-106, (2017)

Guo J., Yiqiang J., Yuan W., Bin Z., Thermal storage and thermal management properties of a novel ventilated mortar block integrated with phase change material for floor heating: an experimental study, Energy Conversion and Management, 205, 112288, (2020)

Hu Y., Per K. H., A new ventilated window with PCM heat exchanger-Performance analysis and design optimization, Energy and Buildings, 169, 185-194, (2018)

Kong X., Lu W., Han L., Guangpu Y., Chengqiang Y., Experimental study on a novel hybrid system of active composite PCM wall and solar thermal system for clean heating supply in winter, Solar Energy, 195, 259-270, (2020)

Li S., Kaikai Z., Gaofeng S., Xiaosong Z., Simulation research on the dynamic thermal performance of a novel triple-glazed window filled with PCM, Sustainable Cities and Society, 40, 266-273 (2018)

Lin Y., Yuting J., Guruprasad A., Guiyin F., Review on thermal conductivity enhancement, thermal properties and applications of phase change materials in thermal energy storage, Renewable and Sustainable Energy Reviews, 82 (3), 2730-2742, (2018)

Lu S., Bowen X., Xiaolei T., Experimental study on double pipe PCM floor heating system under different operation strategies, Renewable Energy, 145, 1280-1291, (2020)

Magendran S. S., Fahad S. A. K., Mubarak N. M., Mahesh V., Rashmi W., Mohammad K., Abdullah E. C., Sabzoi N., Rama R. K., Synthesis of organic phase change materials (PCM) for energy storage applications: A review, Nano-Structures \& Nano-Objects, 20, 100399, (2019)

Magendran S. S., Fahad S. A. K., Mubarak N. M., Mohammad K., Rashmi W., Abdullah E. C., Sabzoi N., Rama R. K., Synthesis of organic phase change materials by using carbon nanotubes as filler material, Nano-Structures \& Nano-Objects, 19, 100361, (2019)

Mays A. E., Rami A., Hawa M., Mahamad A. A., Farouk H., Mahmoud K., Mohamad R., Using phase change material in under floor heating, Energy Procedia, 119, 806-811, (2017)

Rathore P. K. S., Shailendra K. S., Potential of macroencapsulated pcm for thermal energy storage in buildings: A comprehensive review, Construction and Building Materials, 225, 723-744, (2019) 
Wang H., Wei L., Zhigen W., Guanhua Z., Parametric analysis of applying PCM wallboards for energy saving in high-rise lightweight buildings in Shanghai, Renewable Energy, 145, 52-64, (2020)

Weinläder H., Felix K., Modar Y., PCM cooling ceilings in the Energy Efficiency Center - Regeneration behaviour of two different system designs, Energy and Buildings, 156, 70-77, (2017)

Yasin M., Eva S., Felix K., Helmut W., Stephan W., Generation of a simulation model for chilled PCM ceilings in TRNSYS and validation with real scale building data, Journal of Building Engineering, 22, 372-382, (2019)

Yun B. Y., Sungwoong Y., Hyun M. C., Seong J. C., Sumin K., Design and analysis of phase change material based floor heating system for thermal energy storage, Environmental Research, 173, 480-488, (2019)

\section{O RECENZIE PRIVIND PERFORMANȚA ENERGETICĂ ȘI EFICIENȚA SISTEMELOR DE ÎNCĂLZARE PRIN PARDOSEALĂ AVÂND INTEGRATE MATERIALE CU SCHIMBARE DE FAZĂ}

\section{(Rezumat)}

În societatea modernă, conceptul de eficiență energetică a clădirilor a devenit un subiect de mare interes, datorită impactului negativ al clădirilor asupra mediului, societății și economiei. Una dintre metodele de soluţionare a acestor dezavantaje este de a oferi o eficiență mai bună a stocării energiei, deoarece este cheia pentru a rezolva diferența dintre cerere și ofertă. În comparație cu bateriile electrochimice care asigură o stocare limitată a energiei la un cost financiar ridicat, tehnologiile de stocare a energiei termice cu densitate ridicată de energie au potențial crescut. Materialele cu schimbare de fază (PCM) prezintă avantaje obiective în comparaţie cu materialele de construcție clasice datorită caracteristicilor lor de a putea stoca și elibera cantități sporite de energie termică în timpul procesului de schimbare a fazei. Un sistem de încălzire prin pardoseală cu PCM poate asigura o reducere a consumului de energie pentru încălzire cu până la $43 \%$, prin timpul de rărcire mai mare a PCM-urilor în comparație cu sistemele de încălzire obişnuite. 